\title{
Siegfried Kracauer e a teoria do romance policial
}

\author{
Leandro Candido de Souza ${ }^{1}$
}

Para Carlos Eduardo Jordão Machado (in memoriam)

\section{Resumo:}

A partir de 1922, Siegfried Kracauer escreveu uma série de textos que comporiam o livro $O$ romance policial: um tratado filosófico, mas que só seriam publicados em 1971, no primeiro volume de seus Escritos póstumos. O presente artigo tem como objetivo reconstituir a teoria do romance policial formulada por Kracauer, buscando analisar como essa teoria foi fundamentada e quais eram suas principais definições. Inicialmente, o intuito é localizar essa teoria dentro do pensamento mais geral do autor, relacionando-a a sua produção anterior e, principalmente, posterior. Em um segundo momento, tentaremos dimensionar a interlocução estabelecida entre Kracauer e autores do chamado marxismo ocidental, como György Lukács, Walter Benjamin, Theodor Adorno entre outros.

Palavras-chave: Siegfried Kracauer; romance policial; teoria estética; marxismo ocidental.

\section{Siegfried Kracauer and the detective story theory}

\begin{abstract}
:
Starting in 1922, Siegfried Kracauer wrote a series of texts that would make up the book The detective novel: a philosophical tract, which would only be published in 1971, in the first volume of his posthumous Schriften. This paper aims to reconstruct the detective novel theory formulated by Kracauer, seeking to analyze the bases of this theory and its key definitions. The initial purpose is to find this theory's place within the author's more general thinking, relating it to his previous and, especially, later writings. Next, an attempt is made to size up the interlocution established between Kracauer and so-called Western Marxism authors, such as Gyorgy Lukacs, Walter Benjamin, Theodor Adorno and others
\end{abstract}

Keywords: Siegfried Kracauer; detective novel; aesthetic theory; Western Marxism.

\footnotetext{
${ }^{1}$ Doutor em História pela Pontifícia Universidade Católica de São Paulo (PUC-SP). Supervisor de tutoria EaD (Ciências Sociais) da Universidade Brasil. E-mail: lecanza@yahoo.com.
} 


\section{Desamparo transcendental: racionalização e reificação}

A teoria dos gêneros literários que abarcam histórias de crimes publicadas em folhetins, romances policiais e best sellers de suspense (thrillers) indica-nos um dos muitos objetos constantes na reflexão cultural marxista. Esboçada pelo jovem Karl Marx nos comentários sobre Os mistérios de Paris, de Eugène Sue, em A sagrada família, essa linha chega a seu ponto conclusivo em Delícias do crime, de Ernest Mandel, abrangendo nesse ínterim boa parte do conceito de "marxismo ocidental": Walter Benjamin, Antonio Gramsci, Bertolt Brecht, Ernst Bloch entre outros. Dentro dessa tradição, o primeiro pensador a formular uma teoria coerente e minuciosa sobre esse gênero foi Siegfried Kracauer, entre os anos de 1922 e 1925.

Nesses textos, mantidos inéditos até $1971^{2}$, Kracauer inaugurava, a partir dos meios consagrados pela filosofia clássica, seu estudo dos fenômenos considerados marginais da cultura burguesa, o que o levou a reconhecer nos romances policiais a existência de uma estrutura formal que evidenciaria a lógica operacional da cultura capitalista desenvolvida. Desse modo, Kracauer antecipava a ideia de que o esteticamente inautêntico pode revelar algo autêntico da realidade circundante; neste caso, o espalhamento contemporâneo da literatura no campo mais geral da cultura e, portanto, das ideologias.

Houve, porém, uma diferença com relação aos demais autores. Em Kracauer, a fascinação pelo baixo, superficial ou aparente deflagrou uma reorganização do pensar que o conduziu à desconstrução dos sistemas filosóficos tradicionais, o que não vemos ocorrer em todos os citados. Uma desconstrução que foi alimentada tanto pela crítica kierkegaardiana a Hegel, quanto pela sociologia alemã nascente e pela teoria geral do romance de Lukács, apresentada em livro no ano de 1916. Daí vêm os principais elementos da cosmovisão subjacente a $O$ romance policial: um tratado filosófico: a visão da modernidade como movimento de perda crescente da vida, de dissociação entre verdade e existência, devida, acima de tudo, à racionalização.

As origens desse percurso podem ser vistas já na resenha de $A$ teoria do romance que Kracauer publicou em duas versões diferentes, em setembro e outubro de 1921. Na ocasião, já lhe interessava a visão da contemporaneidade como um "processo de desagregação" entre indivíduo e mundo, sujeito e objetividade, interior e exterior, como prescrito pela obra lukacsiana (MACHADO, 2007, p. 186). Segundo Kracauer, foi precisamente esse estado de tensão característico ao mundo burguês, essa “incisão inaudita" entre alma e forma, que engendrou a especificação formal do romance policial.

\footnotetext{
2 Exceção feita ao capítulo O saguão de hotel, publicado pela primeira vez em 1963, junto ao ensaio $\mathrm{O}$ ornamento da massa, em coletânea homônima.
} 
Se na resenha de 1921 vemos, pela primeira vez, a inspiração lukacsiana do desamparo transcendental do homem moderno em decorrência do "desaparecimento do sentido do mundo", em Der Detektiv-Roman essa condição de "sem-teto transcendental" se associa a Kierkegaard na definição do mundo romanesco como a infinitude sem margem em uma época de degradação. Uma inflexão definitiva que será mais bem assinalada por outra resenha, publicada em 1926, sobre a tradução do Antigo Testamento para o alemão, por Martin Buber e Franz Rosenzweig (KRACAUER, 2009, pp. 20520), na qual Kracauer concluiu que o acesso à verdade a partir do profano exigia uma alteração nas formas convencionais da escrita. Mudança que assumirá sua forma definitiva com Os empregados (1930), originando sua "literatura sociológica" (MACHADO, 2012, p. 164).

Endossando a leitura de Carlos Eduardo Jordão Machado, Francisco García Chicote sustenta que, após sua resenha da bíblia, "Kracauer desdobra uma formulação própria da teoria e práxis marxista que tanto se afasta das posturas mecanicistas herdeiras da II Internacional, como de perspectivas lukacsianas de História e consciência de classe" (CHICOTE, 2012, p. 152). Kracauer achava que nesse livro os extremos, os opostos e a transcendentalidade se resolviam convencionalmente na rigidez de um sistema idealista. Foi essa constatação que fortaleceu seu materialismo próprio (sua "dialética material"), construída a partir e contra Lukács, a qual buscava eliminar o sistema de tipo hegeliano identificado no filósofo húngaro. Se o jovem Lukács havia fascinado Kracauer por seu objetivo de firmar uma "ética por meio do conceito de forma", a rigidez e o esquematismo assumidos em História e consciência de classe desencorajaram o alemão de acompanhar seus principais desdobramentos.

Em contraposição ao sistema lukacsiano, Kracauer nos ofereceu uma forma calcada na experiência pessoal ("observação participante" nos Empregados), o que impôs a abertura e inconclusão expositiva própria ao ensaio. Como definiu Theodor Adorno, "[n]este olhar colado à coisa, nós encontramos, no lugar da teoria, o próprio Kracauer” (ADORNO, 2009, p. 270). Essa combinação ensaística entre sociologia, materialismo e forma literária mostra que o caminho assumido foi, de fato, aquele apontado na conhecida abertura de O ornamento da massa (1927): "O lugar que uma época ocupa no processo histórico pode ser determinado de modo muito mais pertinente a partir da análise de suas discretas manifestações de superfície do que dos juízos da época sobre si mesma." (KRACAUER, 2009, p. 91) Desde então, o recurso à superfície, esboçado pela primeira vez na análise dos romances policiais, afastou-se de qualquer aspiração à substância "real", tornando-se um plano que intenta impugnar a verticalidade da filosofia idealista. Novamente nas palavras de Adorno: 
A influência de Simmel exercida sobre ele revela mais da atitude intelectual que de uma afinidade eletiva com o vitalismo irracionalista. Mais tarde ele encontra a fenomenologia na pessoa de Max Scheler, bem antes daquela de Husserl. Seu livro A sociologia como ciência (1922) se esforça notadamente em religar o interesse materialista e sociológico às reflexões epistemológicas fundadas sobre o método fenomenológico. (ADORNO, 2009, p. 267)

O que Kracauer extraiu com radicalidade das formulações de Simmel foi, fundamentalmente, a problemática da "unidade de sentido" que associa a profanação do objeto enquanto posição na tradição teórica à participação do indivíduo na construção desse objeto, engendrando sua forma ensaística própria. Para nosso autor, somente "em uma época em que o sentido se tornou alienado", todo e qualquer fenômeno, coisa ou indivíduo se apresenta como "suscetível de significados infinitos", fazendo com que sua imagem final seja resultado "de sua própria essência e da de seu observador" (KRACAUER, 2009, p. 275). Esse é o eixo principal de sua teoria do romance policial: a eliminação dos indícios de uma vida comunitária referencial, a qual lança as bases de sua posterior "caracterização fenomenológica das grandes urbes" (VEDDA, 2013, p. 80).

\section{Mistérios do marxismo ocidental}

Como tentamos demonstrar até aqui, em O ornamento da massa (1927), Kracauer começou a dar unidade, em um plano horizontal, às investigações dos fenômenos da vida cotidiana detectados nos escombros da cultura burguesa. Como o herói romanesco definido pelo jovem Lukács, o pesquisador se torna, ele também, um indivíduo que busca evidências materiais (no sentido detetivesco) da negatividade da história, explicando em alguma medida seu recurso à "fantasmagoria", a qual também aparece em Bloch, Adorno e Benjamin, comprovando a fecundidade da interlocução. Assim, a compreensão da espacialidade do "saguão de hotel" (in $O$ romance policial), aquele "ir-e-vir de desconhecidos que se tornaram formas vazias porque perderam suas senhas de identificação e perambulam como inapreensíveis fantasmas" (KRACAUER, 2009, pp. 200-1), aflui para uma segunda definição, muito mais geral em seu pensamento, a da "distração" (ou "dispersão") [Zerstreuung].

Posteriormente, sua biografia de Jacques Offenbach, escrita no exílio parisiense, entre 1934 e 1937, também considerará que os fatos ali retratados davam "certa atualidade à fantasmagoria do II Império" (KRACAUER, 1946, p. 12). O início dessa conceituação que leva adiante, por meio da análise da cultura de massas, a ideia de fantasmas da modernidade desencantada, antecede em duas décadas a "indústria cultural" de Adorno e Horkheimer. Kracauer chegou, inclusive, a falar em "fábricas americanas de distração" e 
"espetáculos" que se tornam "foco de interesse estético". E, ao menos desde 1926, ele já acenava para um "culto da distração", acrescentando: "Como os saguões de hotéis, [os cineteatros] são locais de culto do prazer, o seu brilho visa à edificação.” (KRACAUER, 2009, p. 343)

Esse é o substrato do que poderíamos chamar de "teoria literária” de Kracauer, na qual o gênero detetivesco é encarado como uma "forma paroxística" que "não aspira a oferecer a reprodução exata do capitalismo desenvolvido, mas a destacar o caráter intelectualista dessa realidade" (VEDDA, 2013, p. 80). Sua forma específica exacerba, portanto, a estrutura social em que se radica, isto é, a liquidação da cultura e a divinização da ratio. O detetive substitui o sacerdote e o mago de outrora, assim como o saguão de hotel o faz com o templo sagrado, havendo aqui a confirmação de um aprendizado que se originou tanto nas histórias policias quanto na psicanálise: a ideia de que "a substância de uma época se extrai a partir de detalhes inadvertidos".

\footnotetext{
Kracauer aspira a transformar os recursos do jornalismo - o informe, a reportagem - com vistas a convertê-los em instrumentos estética e ideologicamente revulsivos. (...) Convencido das limitações do pensamento abstrato, promove - como Proust, como Benjamin - um pensamento pródigo em imagens e, antes de tudo, em metáforas. (VEDDA, 2013, p. 83)
}

Sua definição de metáfora, estabelecida em “Georg Simmel” (1920-1), prediz que a analogia "se limita a aproximar certos processos segundo seu próprio percurso", ao passo que a metáfora "fornece a explicação de um fenômeno" ou conduz a uma alegoria que pode nos ajudar a pensar. Em outras palavras, a última "circunscreve a impressão que o fenômeno produz em nós, a nossa interpretação, e reproduz na imagem o significado, o conteúdo substancial do fenômeno" (KRACAUER, 2009, p. 255). De modo semelhante, em 1928, Kracauer reconheceu em Walter Benjamin uma escrita alegórica e um olhar melancólico que ocasionavam uma "antítese da generalização abstrata" própria aos sistemas filosóficos, algo que lhe era muito caro, ao menos desde suas leituras de Simmel. Sua admiração por Benjamin vinha sobretudo dessa demonstração de que "as questões grandes são pequenas, e as pequenas, grandes"; mas também da "apoteose como signo da salvação" e de sua intenção especulativa de escavar momentos ocultos da história: "De modo semelhante, Benjamin pode se denominar um agente secreto, no mesmo sentido em que Kierkegaard se definia como um 'agente secreto da Cristandade'."

De Kierkegaard, Kracauer absorveu a "singularidade da fé" e da "subjetividade", as quais demonstram o verdadeiro trauma da imortalidade e as exigências éticas que dela decorrem. Para o pensamento pós-idealista em que Kracauer se inspira, a repetição é, ela própria, a prova da dupla 
impossibilidade de (primeiro) se atingir o significado e (segundo) não gerar nenhum significado novo ao longo desse processo. Eis o cerne da negatividade tocado por Kracauer, o que se confirma na evocada "ontologia negativa", nas páginas de seu tratado sobre o romance policial. Como percebeu Adorno, Kracauer assumiu essa posição ao tomar Kierkegaard como pensador antiHegel por excelência, numa proximidade que se deveu à necessidade de refletir sobre "fenômenos apócrifos" que se apresentam como "alegorias históricofilosóficas como, por exemplo, o romance policial que é mais que um capricho literário" (ADORNO, 2009, p. 271). Mais um aspecto de plena concordância com Benjamin.

Em Casa mobiliada. Principesca. Dez cômodos (Rua de mão única, 1928), Benjamin falou do romance policial como a única apresentação satisfatória do mobiliário do interior burguês da segunda metade do século XIX: "A exuberância sem alma do mobiliário só se torna conforto verdadeiro diante do cadáver." E o fato de Edgar Allan Poe tê-los descrito ainda na primeira metade daquele século, não desmente a retroatividade defendida pelo alemão, uma vez que "os grandes escritores, sem exceção, fazem suas combinações em um mundo que vem depois deles, como as ruas parisienses nos poemas de Baudelaire só existiram depois de 1900 e também não antes disso os seres humanos de Dostoiévski” (BENJAMIN, 2012, p. 13).

Esse caráter da casa burguesa, que estremece pelo assassino sem nome como uma velha lasciva pelo galã, foi penetrado por alguns autores que, qualificados como "escritores criminais" [Kriminalschriftsteller] - talvez também porque em seus escritos se estampa um pouco do pandemônio burguês -, foram privados de suas devidas honras. Conan Doyle tem aquilo que deve ser atingido aqui em alguns de seus escritos; em uma grande produção a escritora A. K. Green o põe em evidência, e com o Fantasma da ópera, um dos grandes romances sobre o século XIX, Gaston Leroux promoveu esse gênero à apoteose. (BENJAMIN, 2012, p. 13)

Dois anos depois, em Romances policiais, nas viagens, pensando em Simmel, Benjamin analisou o ritual de "fazer suas compras no chassi de bandeirolas coloridas na plataforma da estação". Para Benjamin, o viajante que prefere comprar livros nas estações de trens a trazê-los de sua biblioteca pessoal, embarca em uma experiência tipicamente moderna que é determinante no sucesso das brochuras policiais, chegando até mesmo a consignar que "qualquer um conhece o culto ao qual ele [o ritual de compra] nos convida” (BENJAMIN, 2012, p. 224). Uma situação nova cuja base material Benjamin indicará com maior precisão anos depois, em Paris do II Império: a conotação subjetiva dessa transferência do culto à cultura. 
As consequências sociais da mercantilização da literatura3 fizeram das bancas de jornal "as bibliotecas do flâneur" (BENJAMIN, 1989, p. 35) que, desse modo, torna-se um "botânico do asfalto", o qual tem como pré-condição a urbanidade própria ao mundo pós-Haussmann. Vistas por esse ângulo, as fisiologias da primeira metade do século XIX anteciparam formalmente essa nova literatura ao também atenderem ao intuito burguês de "fornecer aos habitantes dos centros urbanos uma ideia amistosa das outras". E acabaram tecendo, a seu modo, uma "fantasmagoria da vida parisiense" (BENJAMIN, 1989, p. 36) que influenciou grandes escritores, incrementando, por exemplo, as intrigas balzaquianas, já ricas "em variações intermediárias entre histórias de índios e de detetives” (BENJAMIN, 1989, p. 40)4.

Para a criminalística [a fotografia] não significa menos que a invenção da imprensa para a literatura. Pela primeira vez, a fotografia permite registrar os vestígios duradouros e inequívocos de um ser humano. O romance policial se forma no momento em que estava garantida essa conquista - a mais decisiva de todas - sobre o incógnito do ser humano. Desde então, não se pode pretender um fim para as tentativas de fixá-lo na ação e na palavra. (BENJAMIN, 1989, p. 45)

As afinidades entre Benjamin e Kracauer até aqui são evidentes: a assistematicidade, a escrita ensaística particular, o interesse pela cultura de massa e a experiência que ela instaura, a associação entre técnica, ratio e modernidade, o apego aos objetos ignorados pela tradição institucionalizada, a influência das fisiologias e a tentativa de atualizá-las 5 . No caso específico de Benjamin, o incógnito representado pela multidão massificada ergue-se como uma ameaça que está no âmago do romance policial: "Em tempos de terror, quando cada qual tem em si algo do conspirador, o papel do detetive pode também ser desempenhado. Para tal a flânerie oferece as melhores perspectivas." (BENJAMIN, 1989, p. 38) Nos fragmentos daquilo que

\footnotetext{
3 Em seus Pequenos trechos sobre arte, Benjamin retoma: "Nem todos os livros se leem da mesma maneira. Romances, por exemplo, existem para serem devorados. Lê-los é uma volúpia da incorporação. Não é empatia. O leitor não se coloca na posição do herói, mas se incorpora ao que sucede a este. (...) Ao comer, se for preciso, leia-se o jornal. Mas jamais um romance. São obrigações que se excluem." (BENJAMIN, 2012, p. 283)

4 No entanto, a influência mais decisiva na gênese do romance policial provavelmente tenha sido a de J. F. Cooper, refletida já no título de Os moicanos de Paris de Alexandre Dumas e em Os mistérios de Paris (1842-3) de Eugène Sue, o qual se refere ao autor de $O$ último dos moicanos logo na abertura. David Harvey comentou em seu detalhado estudo sobre a Paris do século XIX: "Antes de Baudelaire ter lançado seu manifesto das artes visuais (e um século antes de Benjamin tentar decifrar os mitos da modernidade no inacabado projeto das Passagens de Paris), Balzac já havia colocado os mitos da modernidade sob o microscópio e usado a figura do flâneur para fazê-lo", acrescentando, linhas abaixo, que o famoso romance de Sue ajudou a moldar "a imaginação popular em relação ao que a cidade era e poderia se tornar" (HARVEY, 2003, pp. 24-5).

5 Benjamin considerou Os empregados de Kracauer uma "contribuição à fisiologia do capital" (BENJAMIN, 2008).
} 
poderíamos identificar como os indícios de sua teoria do romance policial, as narrativas desse gênero são vistas como inteiramente obedientes aos ritmos da cidade: "Qualquer pista seguida pelo flâneur vai conduzi-lo a um crime. Com isso se compreende como o romance policial, a despeito de seu sóbrio calculismo, também colabora na fantasmagoria da vida parisiense." (BENJAMIN, 1989, p. 39)

O romance policial, cujo interesse reside numa construção lógica, que, como tal, a novela criminal não precisa possuir, aparece na França pela primeira vez com a tradução dos contos de Poe: $O$ mistério de Marie Rogêt, Os crimes da Rua Morgue, A carta roubada. Ao traduzir esses modelos, Baudelaire adotou o gênero. Sua própria obra foi totalmente perpassada pela de Poe; e Baudelaire sublinha esse fato ao se fazer solidário ao método no qual se combinam os diversos gêneros a que Poe se dedicou. (BENJAMIN, 1989, p. 40)

Além de registrar "a perda de vestígios que acompanham o desaparecimento do ser humano nas massas das cidades grandes", a obra de Poe atendia ao postulado baudelairiano de associação entre arte, ciência e filosofia. Por isso Benjamin chega a firmar pouco adiante: "A análise desse gênero literário [detetivesco] já é a análise da própria obra de Baudelaire, apesar de ele não ter produzido nenhuma peça desse tipo.” (BENJAMIN, 1989, p. 40) Esse aparente paradoxo em que se firmam as considerações benjaminianas destaca uma diferença notável entre os dois poetas: Baudelaire jamais escreveu um romance policial porque "em função da impulsividade de seu caráter a identificação com o detetive lhe foi impossível”.

\section{A teoria do romance policial}

A maturidade alcançada pelo pensamento de Kracauer em "O ornamento da massa" é um desdobramento crítico dessas ideias desenvolvidas em sua teoria do romance policial, entre 1922 e 1925. O fundo filosófico das esferas no tratado literário coincide, grosso modo, com a análise do superficial, segundo a qual o periférico, secundário, baixo ou residual apresenta, invariavelmente, algo de autêntico em sua inautenticidade. Sua própria desfortuna teórica seria, assim, sua maior recompensa ao afastá-lo da vigilância da ratio, permitindo o acesso ao "oculto" da história que se encontra escondido na superfície dos fenômenos, como na "carta roubada" de Poé.

Era isso que seu tratado demonstrava, como a estrutura formal do romance policial gerou um gênero estilístico bem definido que exibe "um mundo próprio com meios estéticos próprios”, no qual a percepção do

\footnotetext{
${ }^{6}$ Essa relação entre a teoria da superfície e a carta roubada no conto de Poe é referida pelo próprio Kracauer em Os empregados.
} 
Absoluto "se apresenta como vivência (Erlebnis) intuitiva". Pode-se dizer que cada capítulo do tratado de Kracauer é uma demonstração ou localização de momentos dessa constituição formal que expressam o "aspecto autêntico" de sua "inautenticidade". Falando em termos que nos remetem a Kierkegaard, o homem é tido como um ser de "natureza intermediária", em uma constante tensão entre as esferas de cima e de baixo, de modo que as inferiores esboçam uma "imagem deformada" das elevadas: uma "caricatura da substância perversa" do processo civilizatório, da "ideia de uma sociedade civilizada completamente racionalizada" (KRACAUER, 2010, pp. 24-5).

Muitas passagens confirmam que, em seus juízos, essa forma reflete claramente a sociedade dominada pela ratio autônoma, numa mescla entre segredo superior e perigo atomizado. Assim como o detetive "descobre o segredo oculto entre os homens, o romance policial revela, através do medium estético, o mistério da sociedade despojada de realidade e de suas marionetes carentes de substância" (KRACAUER, 2010, p. 41). Por esse mesmo motivo Kracauer fala, no segundo capítulo da obra, da psicologia nessa literatura como comprovação de uma "ontologia negativa" que elimina a subjetividade7: "cada determinação psicológica é, por conseguinte, um obstáculo colocado de propósito, que a ratio condenada ao triunfo deve superar".

A totalidade estética do romance policial se constituiria a partir "da neblina original que envolve o saguão de hotel” (KRACAUER, 2010, p. 73), e sua fixidez formal segue o imperativo da repetição, confirmando a força motriz que regula a sociedade civilizada completamente estabelecida. Na medida em que se afasta da tensão entre as esferas que caracteriza a ética, o anti-herói das histórias de crime "vaga no espaço vazio entre as figuras na qualidade de representante da ratio". Mas, antes de se dirigir a ela, personifica-a: o detetive não é trágico ou dramático porque ele é vazio de experiência, não está em tensão. Ele é uma negação do que caracteriza um herói, "como a ratio não admite um eu, lhe está proibido relacionar-se com o mundo aparente" (KRACAUER, 2010, p. 75).

Se a ratio é, por excelência, "o pensamento que oscila livremente no vazio, que só se refere a seu vazio profano" (KRACAUER, 2010, p. 81), então um elemento de impessoalidade aboia dessa estilização de um mundo nascido e governado pelo cálculo: para que o meio de sua manifestação se viabilize é necessária a despersonalização do investigador. Desse modo, o que define o detetive como guia narrativo é sua dedução intelectual. O detetive é o cura ou monge de um mundo regido pela instrumentalidade, e que Kracauer reconheceu literariamente no Padre Brown de G. K. Chesterton. O detetive refuncionaliza o sacerdote porque este último não é mais pertinente ante o sucesso da ratio. Aqui está a questão ética profunda que envolve a

7 Essa ideia é retomada no último capítulo da obra (cf. KRACAUER, 2010, p. 135). 
secularização das sociedades modernas e essa analogia nas funções sociais dos tipos em lide.

Ambos "operam por ordem superior e, por conseguinte, devem ser interpretados como mandatários da comunidade, enviados do espaço pleno de vida em comum, para completar a obra de união [Verknüpfung] com o Absoluto" (KRACAUER, 2010, p. 34). O que os une em diferença ao herói romanesco clássico é que nenhum dos primeiros se mistura com a vida comum. Kracauer observa, inclusive, como o romance policial recorreu à figura do religioso para atingir esse objetivo estético, uma vez que não existem condições mais propícias à exposição da ratio que pela ausência de desejos própria às relações estabelecidas no plano do não sensível.

O caráter anti-heroico do detetive está precisamente nesse seu afastamento cínico que Ernst Fischer chamou “desumanização”, e que Kracauer, mais à frente, nomeará por "metamorfoses do ser ético-existencial em relações legais” (KRACAUER, 2010, p. 44). Ou seja, as passagens do sacerdote ao aventureiro e deste ao detetive revelam como o "reino das formas" é uma "transitória prefiguração do reino autêntico". É assim que a unidade da construção estética "faz falar um mundo e infunde sentido aos temas ali debatidos" (KRACAUER, 2010, pp. 38-9), algo próximo ao que Jorge Luis Borges reverenciou em Os assassinatos da Rua Morgue: "Poe não queria que o gênero policial fosse um gênero realista, queria que fosse um gênero intelectual, um gênero fantástico se vocês preferem, mas um gênero fantástico da inteligência, não apenas da imaginação.” (BORGES, 1979)

Esse papel duplo de fornecer um contraste estético e assim delimitar a unidade, também é atribuído à figura do policial e sua corporação. Nesse tipo de narrativa, a polícia consiste na "autoridade de cujo aparato (...) também depende o detetive", mas que se encontra destituída de qualquer “superioridade” (KRACAUER, 2010, p. 94). A função policial é, pois, garantir que a vida pública transcorra com sua devida tranquilidade e ordem, enquanto no detetive "a ratio condicionada tem o efeito de elevar o processo a um fim em si mesmo" (KRACAUER, 2010, p. 103).

O sistema [filosófico] surge porque o pensamento se separa com arrogância da realidade e uma vez que este escapou, tem tão poucas possibilidades de voltar a alcançá-la quanto a polícia estilizada no romance policial de avançar até o "porquê" que ela - sem querer expulsa do mero processo que a devoraria se ela não estivesse a cargo da meta desaparecida. (KRACAUER, 2010, p. 105)

Se no círculo formal sob o domínio da racionalidade, a polícia representa a "ordem", estando diretamente ligada à legalização e normalização dos aparatos repressivos de estado, o ilegal "se converte em um evento pontual que, na pura imanência, enfrenta os fatos derivados do princípio de legalidade sem ter com eles a mínima relação" (KRACAUER, 2010, p. 107). Esquecendo 
que a civilização burguesa é simultaneamente civilização e rebelião contra a civilização, o crime e seu autor são tomados como criações autossuficientes que a ratio deve investigar. Eles não são mais que negação do legal e, em alguma medida, justificativa para a existência da ação policial. Verdadeiramente, no romance policial, apenas o ato ilegal outorga motivação e sentido ao fato presente.

A natureza enigmática do romance policial surge, como vemos, da anulação da tensão ética, diferenciando-o, enquanto tratamento da temática do crime, de enredos como os de Sófocles, Shakespeare ou Dostoiévski. O que os diferencia é que, agora, o crime possui a qualidade exclusiva de fator que interrompe violentamente o curso das coisas. Assim, o tratado filosófico de Kracauer define a forma do romance policial como um autêntico gesto da ratio "que se oculta inicialmente para depois manifestar-se com mais clareza e sem ambiguidades". Sua transcendência começa no instante em que "a ratio se separa do legal, não já por indiferença, mas como representante ético" (KRACAUER, 2010, pp. 118-20). Quando, no combate ao ilegal, o detetive se volta contra a lei, ele se assume como "portador consciente do ético" e conectase ao âmbito do supralegal: "O supralegal que ele representa só perturba a lei para dar-lhe um fundamento (...). A ênfase, em todo caso, está colocada na transferência do social, cuja justificação ética só pode se dar em termos psicológicos." (KRACAUER, 2010, p. 124)

Verifica-se uma legitimidade triunfante na ilegalidade do processo cuja ação fundamental é a elucidação do enigma que, em linhas gerais, confirma a realidade preservando-a. Eventuais "evoluções esportivas", ações físicas ou narrações de proezas corporais têm como única função estética "pôr à prova este processo teórico de maneira prática e manifesta" sem, jamais, reivindicar um significado próprio. Por isso o romance policial "se encarrega de que o processo comece no nada”, na fragilidade misteriosa do cadáver desconhecido, numa restrição de sua base de lançamento que "corresponde à pretensão inerente a toda filosofia idealista, a respeito da imanência do começo a partir do nada" (KRACAUER, 2010, 132). Seu ardil estético se desdobraria dessa inviabilidade inicial de deduzir os fatos de seus contextos de origem: "Ao despojar de sentido a ação decisiva e subordinar o acontecimento à contingência, o romance policial põe em evidência seu ponto de partida a completa desrealização.” (KRACAUER, 2010, p. 150)

\section{Crime e humanismo}

Falando quase nos mesmos termos de Kracauer e mencionando seu tratado na bibliografia, Ernest Mandel sinalizou, mais de sessenta anos depois, "o caráter abstrato e racional da trama, o crime e o desmascaramento do assassino" que coroam o romance policial como "auge da racionalidade 
burguesa na literatura”. Sem conflitos e paixões reais, apenas os instintos elementares, as detective stories tratam unicamente de "homens como objetos" que são dominados pelo destino e que se disputam intelectualmente, dando novas provas do "declínio da racionalidade na ideologia e na sociedade burguesa” (MANDEL, 1988, pp. 43-181).

No romance policial, "não é o poder do que acontece o que corta a respiração, mas a impenetrabilidade da cadeia causal que condiciona o fato" (MANDEL, 1998, p. 112). Em outras palavras, sua eficácia está na repetição constante de sua fórmula e naquilo que Brecht chamou "efeito" [thrill] que já não é mais espiritual, mas puramente nervoso (BRECHT, 1973, p. 343). Isso faz com que, num segundo momento, "ainda que o detetive persiga os mesmos objetivos que a polícia”, tudo ocorra "para diferenciá-lo dela e demonstrar sua autonomia". E a "desumanização da morte" enquanto cadáver a ser dissecado no romance policial, torna a causalidade "um quebra-cabeças para ser montado" (MANDEL, 1988, p. 37), singularizando-o.

Isto é o que diferencia o romance policial da literatura "não-trivial" que se ocupa do crime. Não é o mistério do ato criminoso (quem matou quem), mas a trágica ambiguidade da motivação humana e do destino que se situa no âmago de obras como Der Fall Deruga de Ricarda Huch ou Crime e castigo de Dostoiévski, sem citar Macbeth e Édipo Rei. A verdadeira literatura, como a verdadeira arte reflete a sociedade através do "espelho quebrado" da subjetividade do autor, repetindo uma fórmula de Trotsky, reiterada por Terry Eagleton. Na Trivialliteratur esta subjetividade está ausente e a sociedade está "refletida" apenas para servir, com fins comerciais, a algumas prováveis necessidades dos leitores. (MANDEL, 1988, p. 51)

Essa diferenciação crucial nos repete como "o verdadeiro tema dos primeiros romances policiais não é o crime ou o assassinato, mas o enigma”, a luta de intelectos entre o grande detetive e o criminoso, entre o leitor e o autor: "É um jogo com dados viciados. A racionalidade burguesa é a racionalidade do trapaceiro" (MANDEL, 1988, p. 81). Uma atitude anti-humanista que Ernst Fischer associou tanto a uma capitulação ante a inumanidade - "O homem não é nada. O êxito é tudo" - quanto à ideia de um "voo para fora da sociedade", que aparece quando o austríaco fala dos milhões de jovens que "procuram escapar a seus empregos insatisfatórios, às suas vazias ocupações cotidianas, procuram escapar a um tédio já profeticamente analisado por Baudelaire, procuram fugir às obrigações sociais e ideológicas” (FISCHER, 1977, p. 117).

A "perda da realidade", já existente no romantismo, tornou-se "um problema central no derradeiro mundo capitalista, altamente industrializado", propiciando o desenvolvimento de uma tendência que conduz, sempre segundo Fischer, ao "antirromance francês" de Nathalie Sarraute e Alain Robbe-Grillet (FISCHER, 1977, pp. 223-5). Tese que será prontamente 
rechaçada por Lucien Goldmann. Enquanto, para o autor de $A$ necessidade $d a$ arte, o interesse está na degradação do gosto das massas provocado pela industrialização da cultura ${ }^{8}$, Goldmann afirma que a forma assumida pelo romance nos dois escritores citados não decorre de eles procurarem "a todo o custo uma forma original, mas porque a própria estrutura de que participam todos esses elementos mudou de natureza” (GOLDMANN, 1967, p. 174). Mandel, semelhante a Fischer, considerou o novo romance uma tentativa radical de estetização do romance policial (MANDEL, 1988, p. 103), hipótese ignorada por Goldmann.

Mesmo que Fischer compartilhe com Gramsci, Brecht e o Lukács da Estética, a convicção teórica de que uma arte que diverte é legítima ("O anseio por uma arte que simplesmente 'divirta' é legítimo, e ao lado dos inovadores mais originais, há lugar para grande número de artistas secundários”), jamais abriu mão de seus juízos negativos nas análises concretas ${ }^{9}$. E, diferentemente de Goldmann, não chegou a reconhecer que "a transformação qualitativa na natureza do capitalismo ocidental" provoque "a supressão de toda importância essencial do indivíduo e da vida individual” (GOLDMANN, 1967, p. 176), como aparece no novo romance.

Ao desconhecer essa continuidade, porém, Lucien Goldmann criou um ponto cego em sua sociologia do romance, levando-o ao falso enigma da "defasagem de quase um século que separa a descoberta do fenômeno da coisificação [em Marx] do aparecimento do romance sem personagem [novo romance]" (GOLDMANN, 1967, p. 176). Goldmann ignorou que a manifestação literária correspondente antecedeu à própria conceituação ou, verdadeiramente, criou as condições e, em alguma medida, suscitou sua concretização. Afinal, o próprio Marx foi o primeiro a se referir a ela em seus apontamentos sobre o romance de Eugène Sue, contidos em A sagrada família escrito com Engels, em 1844. Dito de outro modo, essa dissolução da personalidade que surge com as histórias populares de crimes e detetives ${ }^{10}$, das

\footnotetext{
${ }^{8}$ Lembremos a passagem em que o autor diz: "O homem, na sociedade industrial, acha-se exposto a numerosos e diversos estímulos e sensações. Seu senso estético não é tábula rasa: foi afetado por toda a massa das mercadorias que, uma vez produzidas, inundam a sua vida desde a mais tenra infância. Seus critérios de apreciação artística são comumente preconceituosos." (FISCHER, 1977, p. 237)

9 Carola Pivetta observa que Lukács se aproximou pela primeira vez do romance policial lato sensu em Anotações sobre Dostoiévski, continuação jamais publicada de sua Teoria do romance, algo que Carlos Eduardo Jordão Machado acrescenta: "Ferenc Fehér tenta compreender a interpretação de Lukács dos romances de Dostoievski como romance policial [Kriminalroman]." (MACHADO, 2004, p. 14)

${ }^{10}$ Sobre a formação desse caldo cultural popular que fomenta a dissolução de alguns elementos literários como a psicologia das personagens, veja-se, além do já referido escrito de Brecht, as anotações de Antonio Gramsci recolhidas no Quaderno 21 (XVII) 1934-1935: Problemi della cultura nazionale italiana $1^{\circ}$ Letteratura popolare (GRAMSCI, 1977, pp. 2.107-35).
} 
quais Kracauer foi um dos primeiros a se ocupar, antecede a existência do próprio conceito de reificação.

Em palavras finais, o romance policial, enquanto virtualidade formal, abarca um problema em comum com o novo romance, a atomização própria a uma sociedade que reduz o indivíduo e, implicitamente, sua biografia e psicologia "ao nível da anedota e do episódio acidental" (GOLDMANN, 1967, p. 174). Esse fenômeno detectado pioneiramente por Kracauer no romance policial, torna-se ainda mais interessante quando notamos que, no afã de explicar essa "supressão de toda importância essencial do indivíduo e da vida individual no seio das estruturas econômicas e, a partir destas, no conjunto da vida social", Goldmann também recorra à "ilusão fantasmagórica" (GOLDMANN, 1967, pp. 176-9) evocada por Marx¹.

Semelhante ao esquadrinhado por Kracauer, ao invés da revelação da verdade, temos a apresentação hiperbólica da negatividade da história, seus fantasmas. Essa foi a tensão que fundamentou sua teoria do romance policial, o que, em sua máxima profundidade, significou uma ruptura com a cultura burguesa e o domínio do idealismo filosófico. A partir de então, até seu exílio em 1933, os textos de Kracauer vagarão por essa zona desconhecida, provisória e indefinida, mas sempre reconhecendo a alienação como parte de sua própria experiência. A fragmentação do sujeito, em termos teológicos e históricos, defronta-se finalmente com o rompimento do feitiço do progresso, assumindo uma luta para que os elementos ontológicos em desintegração possam ser reintegrados por meio de uma prática emancipadora.

\section{Referências bibliográficas}

ADORNO, Theodor W. Notes sur la littérature. Trad. Sibylle Muller. Paris: Champs Essais, 2009 . 438p.

BENJAMIN, Walter. Charles Baudelaire, um lírico no auge do capitalismo. In: Obras escolhidas v. 3. Trad. José Martins Barbosa, Hemerson Alves Baptista. São Paulo: Brasiliense, 1989. 271p.

. Prólogo: sobre la politización de los intelectuales. In: KRACAUER,

Siegfried. Los empleados: un aspecto de la Alemania más reciente. Introd. Ingrid Belke. Trad., postfacio y notas de Miguel Vedda. Barcelona: Editorial Gedisa, 2008. 254p.

\footnotetext{
${ }^{11}$ A passagem goldmanniana diz exatamente: "É esse fenômeno de abolição, de redução ao implícito de um setor extremamente importante das consciências individuais, substituído por uma nova propriedade, de origem puramente social, dos objetos inertes, na medida em que penetram no mercado para aí serem trocados e, a partir daí, a transferência das funções ativas dos homens para os objetos, e essa ilusão fantasmagórica (que Marx assimilou à perspectiva do personagem shakespeariano, para quem saber ler e escrever era uma qualidade natural, e a beleza o resultado de um mérito) que se designa pela expressão extremamente sugestiva de fetichismo da mercadoria e, depois, coisificação.” (GOLDMANN, 1967, 179)
} 
. Rua de mão única. In: Obras escolhidas v. 2 Trad. Rubens Rodrigues Torres Filho e José Carlos Martins Barbosa. 6. ed. rev. São Paulo: Brasiliense, 2012. 285p.

BORGES, Jorge Luis. “El cuento policial.” Borges oral. Buenos Aires: Emecé, 1979, pp. 65-80.

BRECHT, Bertolt. De la popularidad de la novela policíaca. In: El compromiso en literatura y arte. Trad. J. Fontcuberta. Barcelona: Península, 1973, pp. 3417.

CHICOTE, Francisco Manuel García. "La forma del ensayo en Siegfried Kracauer”. In: CIORDIA, Martín; MACHADO, Carlos Eduardo Jordão; VEDDA, Miguel (Orgs.). Filosofías provisorias: reflexiones en torno a ensayos y ensayistas. Buenos Aires: Gorla, 2012, pp. 149-60.

FISCHER. Ernst. A necessidade da arte. 6. ed. Trad. Leandro Konder. Rio de Janeiro: Zahar Editores, 1977. 254p.

GOLDMANN, Lucien. Sociologia do romance. Trad. Álvaro Cabral. Rio de Janeiro: Civilização Brasileira, 1967. 223p.

GRAMSCI, Antonio. Quaderni del carcere v. 3, Quaderni 12-29 (1932-1935). 2. ed. Edizione critica dell'Instituto Gramsci a cura di Valentino Gerratana. Turim: Einaudi, 1977, pp. 1.511-2.362.

HARVEY, David. Paris, capital of modernity. Nova York: Routledge, 2003. 377p.

KRACAUER, Siegfried. Offenbach o el secreto del II Imperio. Trad. Leon Kopp. Buenos Aires: Siglo Veinte, 1946. 302p.

Los empleados: un aspecto de la Alemania más reciente. Introds. de Ingrid Belke y Walter Benjamin. Trad., postfacio y notas de Miguel Vedda. Barcelona: Editorial Gedisa, 2008. 254p.

- O ornamento da massa: ensaios. Trad. Carlos Eduardo Jordão

Machado, Marlene Holzhausen. São Paulo: Cosac Naify, 2009. 384p.

La novela policial: un tratado filosófico. Trad. Silvia Villegas. Buenos Aires: Paidós, 2010. 168p.

MACHADO, Carlos Eduardo Jordão. A exterritorialidade como condição do apátrida transcendental. Sobre Siegfried Kracauer e Georg Lukács. Significação, v. 34, n. 27, pp. 181-206, 2007.

La peculiaridad de la forma ensayo en Siegfried Kracauer: la literatura sociológica. In: Filosofías provisorias: reflexiones en torno a ensayos y ensayistas. Buenos Aires: Gorla, 2012, pp. 161-8.

MANDEL, Ernest. Delícias do crime: história social do romance policial. Trad. Nilton Goldmann. São Paulo: Busca Vida, 1988. 222p.

PIVETTA, Carola Inés. Walter Benjamin, reflexiones en torno al género policial. Recordando Walter Benjamin: justicia, historia y verdad, escrituras de la memoria. III Seminario Internacional Políticas de la Memoria (Centro Cultural de la Memoria Haroldo Conti), 2010, 16p. Disponível em: 
$<$ http://conti.derhuman.jus.gov.ar/2010/10/mesa32/pivetta_mesa_32.pdf $>$, acessado em: 16 fev. 2016.

VEDDA, Miguel. Calles sin recuerdo: la fenomenología de la gran ciudad en Siegfried Kracauer y Walter Benjamin. Impulso, Piracicaba, 23 (57), pp. 79-86, maio/set., 2013.

Como citar:

SOUZA, Leandro Candido de. Siegfried Kracauer e a teoria do romance policial. Verinotio - Revista on-line de Filosofia e Ciências Humanas, Rio das Ostras, v. 26, n. 1, pp. 145-60, jan./jun. 2020.

Data do envio: 15 mar. 2020

Data do aceite: 8 maio 2020 